University for Business and Technology in Kosovo

UBT Knowledge Center

UBT International Conference

2015 UBT International Conference

Nov 7th, 9:00 AM - 5:00 PM

\title{
Web Application for Students and Lecturer of Electrical Engineering Faculty
}

\author{
Genci Sharko \\ Polytechnic University of Tirana, gsharko@gmail.com \\ Anni Dasho Sharko \\ European University of Tirana, anidasho@gmail.com
}

Kadri Manaj

Follow this and additional works at: https://knowledgecenter.ubt-uni.net/conference

Part of the Computer Sciences Commons, and the Digital Communications and Networking Commons

\section{Recommended Citation}

Sharko, Genci; Sharko, Anni Dasho; and Manaj, Kadri, "Web Application for Students and Lecturer of Electrical Engineering Faculty" (2015). UBT International Conference. 92.

https://knowledgecenter.ubt-uni.net/conference/2015/all-events/92

This Event is brought to you for free and open access by the Publication and Journals at UBT Knowledge Center. It has been accepted for inclusion in UBT International Conference by an authorized administrator of UBT Knowledge Center. For more information, please contact knowledge.center@ubt-uni.net. 


\title{
Web Application for Students and Lecturer of Electrical Engineering Faculty
}

\author{
Genci Sharko $^{1}$, Anni Dasho Sharko², Kadri Manaj ${ }^{1}$ \\ ${ }^{1}$ Polytechnic University of Tirana, Electrical Engineering Faculty \\ ${ }^{2}$ Europian University of Tirana, Faculty of Economy and Information Technology \\ \{gsharko ${ }^{1}$, anidasho $\left.{ }^{2}\right\} @$ gmail.com
}

\begin{abstract}
Electrical Engineering Faculty, nowadays needs to develop by their students the "FIE Student MIS Application". Development and usage of Web applications are popular due to the ubiquity of the browser as a client, commented mostly as a thin client. The ability to update and maintain web applications without distributing and installing software on potentially thousands of client computers is a key reason for their popularity. This paper presents the "FIE Student MIS Application" web platform designed for Electrical Engineering Faculty students and their lecturer to support on time correctly without delays and informing online all students and their lecturer receiving online the student's status as per the FIE exam schema: attendance/activation at lecturer/seminar presence $\%$, exam $\%$, project/essay $\%$, final grade of the exam; schedule of lecturers/seminars by day/week/month per class, other information coming from secretary part to all students in general or to one student. The process of implementation of the "FIE Student MIS Application" is based on project management of web application as per: definition, planning, management and evaluation.
\end{abstract}

Keywords: web applications, project management, PhP and MySQL, Student MIS Application.

\section{Introduction}

Development, implementation, and usage of web applications are having a great popularity due to the ability of updating and maintaining web applications without distributing and installing software on all Electrical Engineering Faculty student's computers of Polytechnic University of Tirana for the whole set of applications developed for FIE students' needs and FIE Managerial and Academic staff needs. Web-based applications are: easier to be developed from the development teams, more useful for your users, userfriendly applications, easier to install and maintain and keep secure the whole application already developed, easier to grow as the needs from university come and grow time by time. The Project Management process of Developing Web Applications is based on: Analyses, Development, Testing, Implementation and Usage of Web Applications which are having a great popularity even due to the ability of updating and maintaining web applications without distributing and installing software on potentially all FIE student's computers of Polytechnic University of Tirana. [1] "FIE Students-MIS" web application is the first initiative of web application designed for Polytechnic University of Tirana, Electrical Engineering Faculty, from Electrical Engineering Student where the outcome of students' and lecturers' intranet platform is seen from FIE Management, lecturers and students as an important tool facilitating students and their lectures during the academic year with: Course's syllabuses, lecturer's presentations in power point format, downloaded e-books, mandatory and recommended literature for the courses, video tutorials for different subjects.

The on-line evaluation platform "FIE-On-line lecturers/courses evaluation" web application is the first initiative of web application designed for Electrical Engineering Faculty by electrical engineering students where the outcome of students'/courses evaluation of teaching performance is seen from FIE Management as an important tool to measure the effectiveness of teaching quality of all lecturers/courses for the whole academic staff bachelor and master levels of Electrical Engineering Faculty. 


\section{Web Application Analysis and Definitions}

A Web-based application refers to an application that uses the World Wide Web as a distributed informal retrieval system. The writing process of web applications is often simplified by open source software (Drupal, Ruby or Symphony) so often called web application frameworks. These web application frameworks facilitate the rapid application development process allowing IT development team to focus on the parts of the application which are unique to their goals without having to resolve common development issues such as user management/reporting part. (Lane,Williams, 2004)[3], (Greenspan, Wall,Bulger, 2004)[4].

An intranet is a network that provides services within an organization/university environment that are similar to those provided by the Internet platform, but those services are not mostly connected to the Internet platform. Intranets are typically protected by "firewalls" based on the security policy of the organizations/university environment, where an intranet can be considered as a private internet. Webbased applications can be developed flexibly on both the Internet and Intranets platform of an organization/university environment. A web-based applications typically use web browsers Mozilla Firefox or/and Microsoft Internet Explorer, (mostly we use at our web applications platform Mozilla Firefox) as a platform and HTTP as an additional Internet protocol.

The detailed analyses consisted on several meetings and interviews done with the Faculty Dean and Deputy Dean, Head of Departments the requirements specification document was created for developing web applications as:

"FIE Students-MIS"

"FIE-On-line lecturers/courses evaluation"

Review of existing FIE official documentations helped us on understanding all elements of actual online and traditional hardcopy evaluation process and Intranet documentation platform. The FIE student's main database platform already existing in excel format, was a good reference when working for the final requirements specification document for "FIE-Online Lecture/Courses Evaluation", and "FIE Students-MIS", Web applications.

Project Methodology used:

First phase had the following sub-phases:

- Analysis and Definitions

- Implementation (Active development)

- $\quad$ Backup Policy (daily, weekly during the evaluation period per each semester).

Second phase had the following sub-phases:

- $\quad$ Final preparation (Migration, Integration tests, Documentation, user training)

- Go Live in 2 phases

- First Phase testing with Bachelor Students of Electrical Engineering Faculty, during the end of the Electrical Measurement Subject for both applications.

- Second phase Go-Live with full versions of both web applications.

In general, all FIE students accessing the application form Intranet or Internet environment found the importance of such application and how useful was for all students both web platforms: FIE-Online Evaluation and FIE-Students MIS. The success or the failure of a software system depends mostly on its utilization. (Zhiming,Woodcock,Huibiao, 2013)[5], (Sommerville, 2012)[6].

\section{Software Design, Data and Software Model}

\section{1 "FIE-Students MIS" Application}

Building up a Management Information System for university environment for sure it needs a unique combination of features. Based on that thinking about building an Students and Lecturers MIS for Electrical Engineering Faclty, Polutechnic University of Tirana Environment, several requirements will come to the fore: to decide on what platform works best for us, we need to analyze these requirements, then evaluate systems based on on-site cost development \& maintenance.

As we all know the concept of Intranet, even for a university environment we have the same properties: private network, admission across firewall, requires authorization, useful for delivering \& sharing information on selective basis. The FIE developer's team went through a deep analyses phase, 
taking into consideration the business requirements of FIE Management and Academic Staff and concluded as hereby:

- FIE Students-MIS should be developed over an open source platform, Joomla or PhP MySQL.

- This system will be able of creating possibilities of adding different items, during the extension of the Project second phase.

- Eligibility for managing FIE student's access (as user's access on the system).

- The system should give access materials by students on the basis of group-level subjects (ie Electrical Engineering Faculty Master Students can access and download materials like lectures in ppt, e-books, other video materials and articles related to the subject. Students will not access other Departments, of the Electrical Faculty or other master or bachelor profiles even inside the Electrical Engineering Faculty if they do not belongs to.

- Lectures of the subjects should have the right to upload materials (lectures in ppt, e-books (mandatory \& recommended literature), only in their subject's folder/semester/academic year and can update each academic year the infrastructure of materials entered supporting their students.

- The FIE Students and Lecturers MIS Administrator has the rights to enter users as per students increase on each master or bachelor level.

- Students can manage their account with details on their presence on the lecturing for the whole simester, project evaluation, exam evaluation, and final evaluation in points and in degree as well.

- They will find there the whole week lecture, seminars and laboratories to be present during hours, days and weeks till the end of the simester and academic year.

Building up the FIE Students \& Lecturer MIS platform: we decided to use the FIE Internet template and to go further on customization and developing to achieve FIE Intranet objectives. For creating the subjects folder, in the menu content management, in the administration panel: it can create categories, add articles etc. Creating Users will only be made by a panel of administration in order to eliminate the creation of accounts by unauthorized persons. Originally must create user groups and then levels of access.

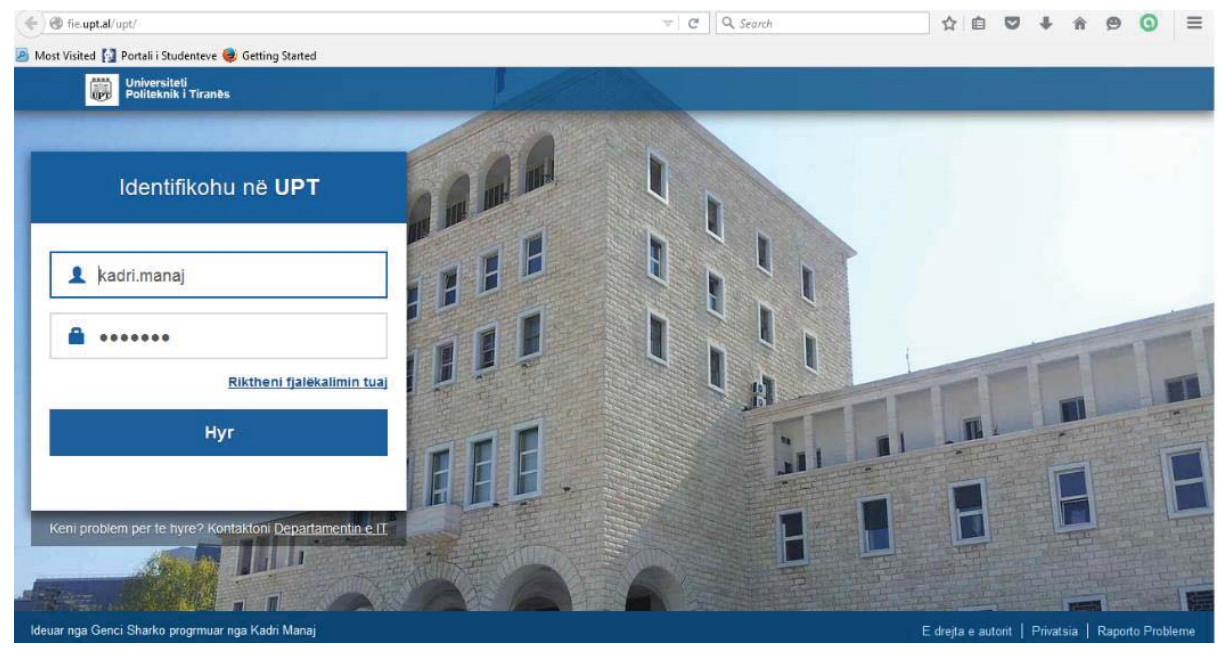

Figure 1. FIE Students and Lecturers MIS.

The second level of access will be the Electrical Engineering Faculty, as group of users as the first main template to be used after for the other faculties of the whole Polytechnic University of Tirana as well on the second phase of the project implementation. The FIE Intranet administrator will create an account for one student of Master Degree „Elektroteknike/Sistemet Elektrike te Fuqise/Automatizimi i Industrise" - Electrical Engineering Faculty, he will choose the Electrical Engineering Faculty as group of users-first level of access. 


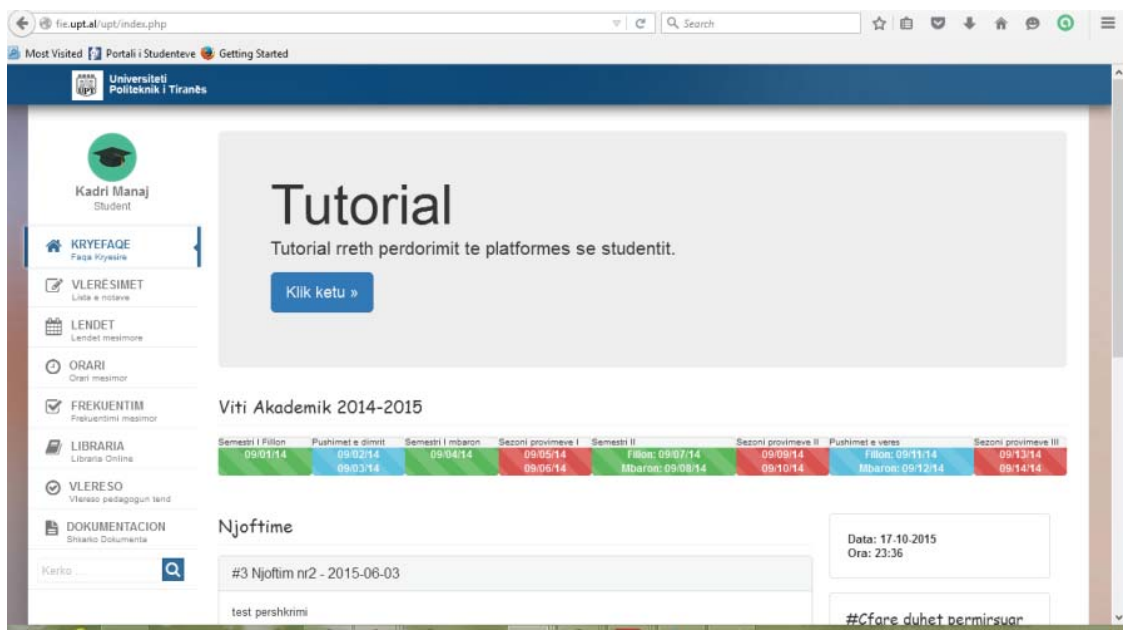

Figure 2. The main page of Students accessing as per their credential the FIE Students MIS platforme.

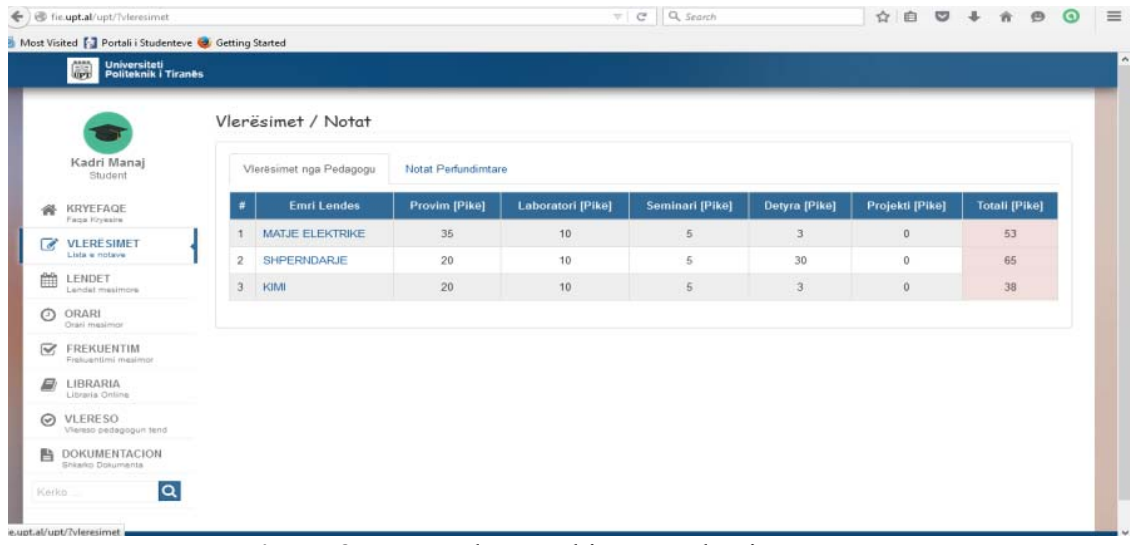

Figure 3. FIE Students Subjects Evaluation Process.

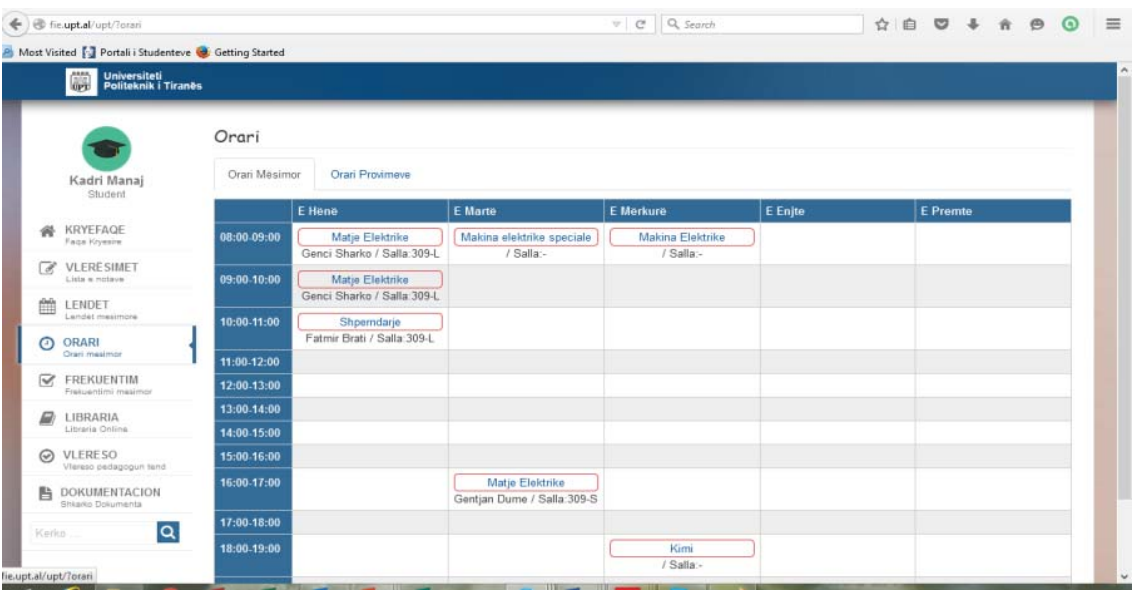

Figure 4. FIE Students Lecturer-Seminars-Laboratiry to be present per hours/days/weeks. 


\section{2 "FIE-Online Lecture/Courses Evaluation" Application}

For FIE On-Line Evaluation Application we have chosen the WAMP platform as a dynamic webbased application of type client-server developed and implemented in a Windows-Apache-MySQLPHP platform. The application is installed once in the server and, all students, lecturer, and the top management staff of FIE can access and use the application.

Realizing such a web application for on-line evaluation process for the lecturing process and courses, the FIE IT team designed this web application based on the platform Apache/MySq1/PHP with following versions of the components: Apache 2.2.14, MySq1 5.1.44, PHP 5, PhpMyAdmin 3.2.4.

Properties of FIE-Online Lecture/Courses Evaluation application are:

- The database of this application will be in MySql, in the next step it will be on SQL.

- The on-line evaluation application will be available over the FIE Intranet/Internet platforms.

- The web application is not depandable from the operating system of the server.

- The application can be accessed from different browsers, but preferable will be Mozilla as per FIE standard web page browser.

- The users have different rights and not overlapping with each other.

- The basic reports is based on the functional requirements elements.

- Automatic email to be sent to all FIE lecturer/management staff after the whole evaluation process is finalized.

During the designing of the "FIE-Online Lecture/Courses Evaluation" Database, we have done the proper analyses based on the main FIE Students Database and a well-designed database took time and efforts to conceive, build and refine, to achieve at the end the proper database structure for the "FIEOnline Lecture/Courses Evaluation" Application.

Vendosni Kodin e Studentit dhe password-in tuaj ne fushat e kerkuara pastaj shtypni butonin Log In

\section{Logohuni}

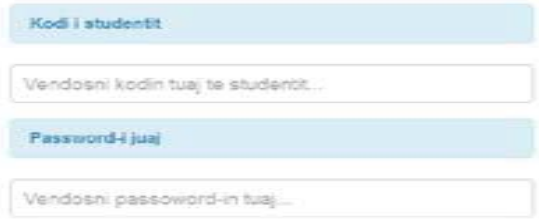

$\log$ in

Fig. 5. Login form for the FIE Students.

Password-i do gjenerohet pasi te keni vendosur Kodin e Studentit ne fushen e kerkuar dhe te shtypni butonin Gjenero Password

Gjenerimi i password-it

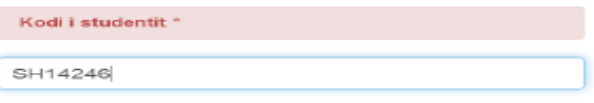

\section{Gjenero Password}

Password-i juaj eshte: 93 de9fao

Klikoni KETU per tu Loguar

Kopjoni Password-in tuaj per tu loguar.

Fig. 6. Password generation based on FIE student's ID and email address. 
International Conference on Computer Science and Communication Engineering, Nov 2015

\begin{tabular}{|c|c|c|c|c|c|c|}
\hline \multicolumn{7}{|l|}{$\begin{array}{l}\text { VITI AKADEMIK } \\
\text { Lënda: } \\
\text { PEdagogu: }\end{array}$} \\
\hline \multicolumn{7}{|c|}{ 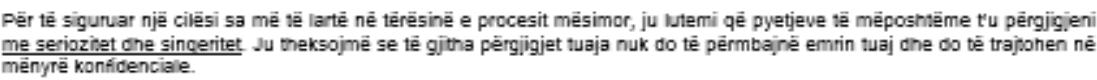 } \\
\hline & $\begin{array}{l}\text { Jam } \\
\text { Plotésisht } \\
\text { Dakord }\end{array}$ & $\begin{array}{l}\text { Jam } \\
\text { Dakord }\end{array}$ & $\begin{array}{l}\text { Jam i } \\
\text { Lêkundur }\end{array}$ & $\begin{array}{l}\text { Nat } \\
\text { jam } \\
\text { dakord }\end{array}$ & $\begin{array}{l}\text { Now jam } \\
\text { aspak } \\
\text { dakord }\end{array}$ & $\begin{array}{l}\text { Nuk } \\
\text { aplikohet }\end{array}$ \\
\hline \multicolumn{7}{|l|}{\begin{tabular}{|l|l|l|l} 
Mëaimahënia \\
\end{tabular}} \\
\hline \multicolumn{7}{|l|}{ 1. Pedagogu snpjegon mirê } \\
\hline \multicolumn{7}{|l|}{ 2. Pedagogu e tên lēndèn interesante } \\
\hline \multicolumn{7}{|l|}{ 3. Pedagogu e zhvilon lêndên me pasion } \\
\hline \multicolumn{7}{|l|}{ 4. Lënda nxit interesin dhe mendimin kritik } \\
\hline \multicolumn{7}{|l|}{$\begin{array}{l}\text { 5. Lénda éshrè e organizuar miré dhe temat } \\
\text { ndërthuren natyrshëm }\end{array}$} \\
\hline \multicolumn{7}{|l|}{\begin{tabular}{|l|} 
Vlerëaimi dhe aqarimi \\
\end{tabular}} \\
\hline \multicolumn{7}{|l|}{$\begin{array}{l}\text { 6. Kniteret e verésimitj jané béré té qarta qé né } \\
\text { filium }\end{array}$} \\
\hline \multicolumn{7}{|l|}{ 7. Vlerésimi i pedagogut ka qenē i drejté } \\
\hline \multicolumn{7}{|l|}{ 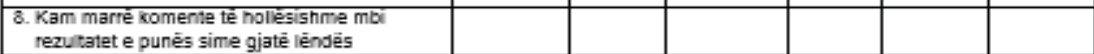 } \\
\hline \multicolumn{7}{|l|}{ 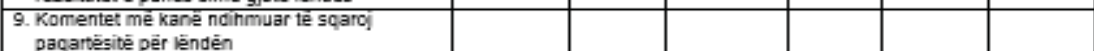 } \\
\hline \multicolumn{7}{|l|}{\begin{tabular}{|l} 
Këshillimi akademik \\
\end{tabular}} \\
\hline \multicolumn{7}{|l|}{$\begin{array}{l}\text { 10. Kam pasur mundési ta kontaktoj pedagogun } \\
\text { sa heré e kam kérkuar }\end{array}$} \\
\hline \multicolumn{7}{|l|}{\begin{tabular}{|l|} 
Vlerësimi i përgijthahëmm \\
\end{tabular}} \\
\hline 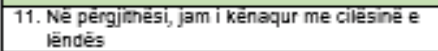 & & & & & & \\
\hline
\end{tabular}

Mbèshtetur në eksperiencēn e tuaj tê deritanishme, nëse dëshironi tē theksoni ndonjē aspekt pozitiv apo negatî tể lëndès, lutemi përdomi hapèsirat mê poshtë:

Pozitive:

Negative:

Faleminderit që morēt pjesē në vlerësimin e pedagogut dhe lëndës!

Fig. 7. Lecturer and Course Evaluation form to be fill in from all students online.

An effective data model completely and accurately represents the data requirements of the end users. The model used for "FIE-Online Lecturers/Courses Evaluation" Application eliminates redundant data, it is independent of any hardware and software constraints, and can be adapted to changing requirements with a minimum of effort.

After the analyses phase based on the collaboration of functional and IT it was agreed for the further steps on the software design part as usually considered as the most crucial one or the success of a FIE On-Line evaluation Application development part. It consists in developing a database and software model which will interact with the database for storing, modifying and retrieving proper data. [2]

The first step in this phase was modeling the real world system in a well-structured database. The next step is the implementation of the software for interacting with the database and most importantly offering a user friendly interface to do so.

The communication between the database and the software includes: storing data/information into the database, modifying data/information already stored in the database, retrieving and consulting data/information. Each user of the application should fill identification requirements in order to login in its personalized interface and use the application and its features. (Runeson, Host, Rainer, Regnell, 2012)[7], (Bell, 2005)[8]. 


\section{Conclusion}

As we all know web-based applications are well-known for easier to be developed from the IT development teams created mos of the times with faculty bachelor and master students at FIE, are more useful for all type of users: students, lecturer or administrative university staff. Easier to be installed and maintained and with high level of security regarding the whole application already developed by the IT development team, easier to be grown as the needs from university come and grow time by time. With the initiative of the Electrical Engineering Faculty Management and Academic Staff it was established a dedicated team of a bachelor student mentored from the Deputy Dean for the development of two web development applications necessity supporting and facilitating students and lecturers during the academic year: a. "FIE-On-line lecturers/course evaluation" through the desktop application platform b. "FIE Students \& Lecturer- MIS" supporting FIE students and their lecturers during the academic year.

Encouraging FIE students' community acceptance and adoption of Web applications calls for initiatives to make such applications more broadly useful to users in their daily activities. To this end, we claim that a path - based incremental development approach, in which users are involved in evaluating each increment, is a good approach for appropriate technology Web applications. The development of this application is done based on the following platforms of: Apache/MySQ1/PHP.

\section{References}

1. Anderson, J. \& Brown, G. \& Spaeth, S. (2006). Online student evaluations and response rates reconsidered, Innovate: Journal of Online Education, 2(6).

2. Thorpe, S. W. (2002 June). Online student evaluation of instruction: An investigation of nonresponse bias. Paper presented at the 42nd Annual Forum of the Association for Institutional Research, Toronto, Ontario, Canada.

3. Lane, D. and Williams, H. E., (2004). Web Database Applications with PHP and MySQL. O'Reilly.

4. Greenspan, J., Wall, D. and Bulger, B. (2004). MySQL/PHP Database Applications. Wiley.

5. Zhiming, L. Woodcock, J. \& Huibiao, Zh. 2013. Unifying Theories of Programming and Formal Engineering Methods. International Training School on Software Engineering Held at ICTAC.

6. Sommerville, I. 2012. Software engineering 9th ed. Addison-Wesley, Pearson Education.

7. Runeson,P. \& Host, M. \& Rainer, A. \& Regnell, B. (2012). Case Study Research in Software Engineering (Guidelines and Examples). John Wiley \& Sons, Inc.

8. Bell, D. (2005). Software Engineering for Students, a programming approach, 4th edition-2005. Addison Wesley-Pearson Education Limited.

9. http://pc.net/helpcenter/answers/static_and_dynamic_web_pages

10. http://www.joomla.org/about-joomla.html

11. http://www.aviontechnology.net/advantages-and-disadvantages-of-joomla-cms- development/ 